\title{
Growth of hydroponic lettuce with optimized mineral and organomineral nutrient solutions
}

\author{
Antonio F. Monteiro Filho' ${ }^{1}$, Márcia R. Q. A. Azevedo ${ }^{1}$, Carlos A. V. de Azevedo², \\ Josely D. Fernandes ${ }^{1}$, Carisa R. da Silva ${ }^{3} \&$ Yuri dos S. Silva ${ }^{1}$ \\ ${ }^{1}$ Universidade Estadual da Paraíba/Centro de Ciências Agrárias e Ambientais. Lagoa Seca, PB. E-mail: zelydf@gmail.com (Corresponding author); \\ mrqazevedo@gmail.com; joselysolo@yahoo.com.br; yurieaac@gmail.com \\ ${ }^{2}$ Universidade Federal de Campina Grande/Centro de Tecnologia e Recursos Naturais/Unidade Acadêmica de Engenharia Agrícola. Campina Grande, \\ PB. E-mail: carlos.azevedo@ufcg.edu.br \\ ${ }^{3}$ Universidade Estadual da Paraíba/Programa de Pós-Graduação em Ciências Agrárias. Campina Grande, PB. E-mail: carisarochasilva@gmail.com
}

Key words:

Lactuca sativa L. horticulure

SOLVER

\begin{abstract}
A B S T R A C T
The objective of this study was to evaluate the growth of crisp lettuce in hydroponic cultivation, following the nutrient film technique (NFT), using optimized mineral and organomineral nutrient solutions. The experiment was set in $8 \times 3$ factorial scheme, with treatments distributed in randomized blocks and split plots, with three replicates. The plots corresponded to eight nutrient solutions, of which four were mineral solutions with chemical composition suggested by Bernardes, Furlani, Castellane \& Araújo and Ueda, and four were organomineral solutions, suggested by this research with chemical composition similar to those of the previously mentioned mineral solutions. The subplots corresponded to three varieties of crisp lettuce: Thaís, Vanda and Verônica. At 25 days after transplanting, the following parameters were evaluated: stem and crown diameter, root length, leaf area and number of leaves. For stem and crown diameters and number of leaves, the mineral solutions promoted the highest means. The mineral solution of Furlani and the organomineral solutions, except the modified solution of Castellane \& Araújo, promoted the greatest root lengths. The smallest leaf area was obtained in the organomineral solution of Ueda. The cultivar Verônica had the highest root length and stem diameter.
\end{abstract}

Palavras-chave:

Lactuca sativa $\mathrm{L}$. horticultura

SOLVER

\section{Crescimento da alface hidropônica cultivada com soluções nutritivas minerais e organominerais otimizadas}

\begin{abstract}
R E S U M O
Objetivou-se, neste trabalho, avaliar o crescimento da alface crespa em cultivo hidropônico, seguindo a técnica do fluxo laminar de nutrientes (NFT), utilizando soluções nutritivas minerais e organominerais otimizadas. Instalou-se um experimento em blocos casualizados com o uso de parcelas subdivididas, com três repetições. As parcelas corresponderam a oito soluções nutritivas, sendo quatro minerais com composição química sugeridas por Bernardes, Furlani, Castellane \& Araújo e Ueda e quatro organominerais, sugeridas nesta pesquisa com composição química semelhante às soluções minerais, anteriormente citadas. As subparcelas corresponderam a três cultivares da alface crespa (Thaís, Vanda e Verônica). Aos 25 dias após o transplantio das mudas avaliaram-se as variáveis diâmetro do caule e da coroa, comprimento da raiz, área foliar e número de folhas. Para os diâmetros da coroa e do caule e número de folhas, as soluções minerais promoveram as maiores médias. A solução mineral de Furlani e as soluções organominerais, exceto a de Castellane \& Araújo modificada, promoveram os maiores comprimentos de raízes; a menor área foliar foi obtida pela solução organomineral de Ueda. A cultivar Verônica apresentou os maiores comprimento de raiz e diâmetro caulinar.
\end{abstract}




\section{INTRODUCTION}

The consumption of vegetables has increased not only due to the population growth, but also because of the trend of change in the food habit of the consumer, making inevitable the need to increase production. A considerable part of the terrestrial ecosystems has been intensively altered by humans and the rhythm of exploitation of natural resources seems to exceed the capacity of regeneration of many of these ecosystems (Potrich et al., 2012).

The cultivation of lettuce in hydroponic systems is already widely spread in Brazil, especially because of its easy management, combined with its short cycle (Silva et al., 2007). Various studies have already been conducted with the cultivation of this vegetable using the technique of hydroponics, such as Magalhães et al. (2010), Paulus et al. (2012) and Sarmento et al. (2014). However, all refer to the use of mineral nutrient solutions, particularly the solution of Furlani (1995). Although scarce, in the last years a few studies on the use of biofertilizer in the production of hydroponic lettuce have been conducted, such as Costa et al. (2006), Dias et al. (2009) and Monteiro Filho et al. (2014).

In an attempt to develop sustainable agricultural systems, family farmers have replaced synthetic inputs by organic inputs mostly produced in their properties. Such practice has demanded increasingly accurate studies on fertility indicators and control of pests and diseases (Alencar et al., 2012).

Biofertilizer is one of the main organic inputs used in agroecological systems, but the lack of tests and information in the search of a standardization limits its exploitation, because each crop has a particular nutritional requirement, which is not taken into consideration during the preparation (Lovatto et al., 2011).

In this context, this study aimed to evaluate the growth of hydroponic lettuce cultivated with different mineral and organomineral solutions optimized using the Solver tool of the Microsoft Office Excel.

\section{Material AND Methods}

The experiment was carried out in the period from May 5 to August 4, 2014, in a hydroponic system, adopting the nutrient film technique (NFT) in a protected environment of the Center of Agricultural and Environmental Sciences (CCAA) of the State University of Paraíba (UEPB), situated in the city of Lagoa Seca-PB ( $7^{\circ} 10^{\prime} 15^{\prime}$ ' S, 35 51' $14^{\prime}$ ' W and mean altitude of $634 \mathrm{~m}$ ). According to Köppen's classification, the climate of the municipality is characterized as humid tropical (As'), with mean annual temperature around $22^{\circ} \mathrm{C}$, minimum of $18^{\circ} \mathrm{C}$ and maximum of $33^{\circ} \mathrm{C}$.

The experiment was in $8 \times 3$ factorial scheme, corresponding to 8 nutrient solutions and 3 cultivars of crisp lettuce, with treatments arranged in randomized blocks and split plots, with three replicates.

Regarding the eight nutrient solutions, four were mineral, with chemical composition proposed by Bernardes (1997), Castellane \& Araújo (1994), Furlani (1995) and Ueda (1990), which were referred to as BM (Bernardes - Mineral), CM
(Castellane \& Araújo - Mineral), FM (Furlani - Mineral) and UM (Ueda - Mineral), respectively. The other four corresponded to modifications made in the present study of the previously mentioned mineral solutions, using biofertilizer, but making their chemical composition similar to those of the mineral solutions, producing four organomineral nutrient solutions, referred to as Bernardes modified (BO), Castellane \& Araújo modified (CO), Furlani modified (FO) and Ueda modified (UO).

The plots represented the nutrient solutions, each one with two hydroponic profiles spaced by $0.30 \mathrm{~m}$ and each with 10 crisp lettuce plants spaced by $0.30 \mathrm{~m}$. The subplots represented the crisp lettuce cultivars (Thaís, Verônica and Vanda) and each subplot was composed of 6 plants of each cultivar.

The modified nutrient solutions were prepared by initially formulating four biofertilizers with the aid of the SOLVER tool, in order to obtain a mixture of organic ingredients with chemical composition similar to those suggested by Ueda, Castellane \& Araújo, Furlani and Bernardes. These biofertilizers were referred to as $\mathrm{BIO} 1, \mathrm{BIO} 2, \mathrm{BIO} 3$ and $\mathrm{BIO} 4$, respectively. Their ingredients were bovine manure, bovine milk, blood of birds from the CCAA/UEPB and molasses acquired in the market of Campina Grande-PB. After formulation, the ingredients were mixed and diluted in $30 \mathrm{~L}$ of reservoir water (rainwater), previously analyzed according to the methods described by APHA (1998). The water showed the following characteristics: $\mathrm{EC}=0.239 \mathrm{dS} \mathrm{m}{ }^{-1} ; \mathrm{pH}=7.3$; and $\mathrm{Ca}^{++}=48.4$; $\mathrm{Mg}^{++}=6.4 ;\left(\mathrm{CaCO}_{3}\right)=147.5 ; \mathrm{K}^{+}=21.7 ; \mathrm{Cl}^{-}=33.4 ; \mathrm{Na}^{+}=4.7$; total $\mathrm{Fe}=0.01 ; \mathrm{SO}_{4}^{-}=3.3 ; \mathrm{P}=0.0 ; \mathrm{NO}_{3}{ }^{-}=0.75$ and $\mathrm{NH}_{4}{ }^{+}=$ $0.15\left(\mathrm{mg} \mathrm{L}^{-1}\right)$.

In order to promote the action of aerobic microorganisms, compressed air was injected into the biofertilizers using an air compressor during the period of 30 days, which guaranteed a concentration of dissolved oxygen close to $2.0 \mathrm{mg} \mathrm{L}^{-1}$. Once the biofertilizers were aged, samples were collected for chemical characterization based on the dry matter, at the laboratory of analyses of soil, water and plant, of the Agricultural Research Company of Rio Grande do Norte (EMPARN), following the methodology described by EMBRAPA (1997). The results are presented in Table 1.

Since the chemical characterization of the biofertilizers showed nutritional concentration inferior to those recommended by Ueda, Castellane \& Araújo, Furlani and Bernardes, they were complemented with mineral fertilizers,

Table 1. Chemical composition of the biofertilizers

\begin{tabular}{lcccc}
\hline \multirow{2}{*}{ Nutrients } & \multicolumn{4}{c}{ Biofertilizer } \\
\cline { 2 - 5 } & BI01 & \multicolumn{4}{c}{ BI02 } & BI03 & BI04 \\
\cline { 2 - 5 } $\mathrm{NH}_{4}{ }^{+}$ & 7.284 & 12.800 & 34.787 & 14.144 \\
$\mathrm{NO}_{3}{ }^{-}$ & 0.004 & 0.004 & 0.010 & 0.004 \\
$\mathrm{P}$ & 4.036 & 14.009 & 66.855 & 56.350 \\
$\mathrm{~K}$ & 35.710 & 79.124 & 23.050 & 14.807 \\
$\mathrm{Ca}$ & 7.748 & 24.708 & 23.083 & 14.807 \\
$\mathrm{Mg}$ & 94.800 & 33.220 & 21.059 & 181.844 \\
$\mathrm{Zn}$ & 0.078 & 0.269 & 0.259 & 0.158 \\
$\mathrm{Fe}$ & 0.493 & 1.300 & 2.328 & 0.884 \\
$\mathrm{Mn}$ & 0.100 & 0.241 & 0.044 & 0.197 \\
$\mathrm{Cu}$ & 0.013 & 0.027 & 0.038 & 0.016 \\
\hline
\end{tabular}

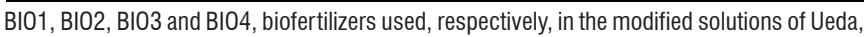
Castellane \& Araújo, Furlani and Bernardes 
according to the methodology proposed by Fernandes et al. (2011).

The crisp lettuce seedlings were produced in phenolic foam according to the methodology described by Monteiro Filho et al. (2014). The plants were evaluated at 25 days after transplanting for the following growth variables: stem diameter (SD) and crown diameter (shoots, CD), obtained through the direct measurement using a digital caliper; root length $(\mathrm{RL})$, using a graduated ruler; leaf area (LA), through the leaf disc method (Benincasa, 2003); number of leaves (NL), through the count of the number of commercial leaves from the basal leaves to the last open leaf.

The obtained results were subjected to the tests of homogeneity (Bartlett) and normality (Shapiro-Wilk). Except for the number of leaves, the growth parameters were subjected to analysis of variance by $\mathrm{F}$ test, at 0.01 and 0.05 probability levels. When significant effect was observed in the analysis of variance, the means obtained in the different treatments were compared by Tukey test at 0.05 probability level. For effect of normality, leaf area data were transformed to $\log \mathrm{x}$. The data of number of leaves did not follow the assumptions of the tests to be subjected to the ANOVA. Therefore, the means were compared by the non-parametric statistics of Kruskal and Wallis. The statistical programs used in the present study were Sisvar (Ferreira, 2014) and Biostat 5.0 (Ayres et al., 2007).

\section{Results AND Discussion}

Based on the analysis of variance (Table 2), there was significant interaction $(\mathrm{p}<0.05)$ between nutrient solution (S) and cultivars (C) only for crown diameter (CD), while the variables root length $(\mathrm{RL})$, stem diameter $(\mathrm{SD})$ and leaf area (LA) were influenced $(\mathrm{p}<0.01)$ by the isolated effect of the nutrient solutions $(\mathrm{S})$. The factor cultivar influenced RL ( $\mathrm{p}<$ $0.05)$ and $\mathrm{SD}(\mathrm{p}<0.01)$.

Except for the modified solution of Ueda (UO), the cultivar Verônica showed the highest means of crown diameter (CD), but without differing statistically from the cultivar Vanda with the use of the modified solution of Bernardes (BO), mineral solutions of Furlani (FM) and Castellane \& Araujo (CM) and from the cultivar Thaís with the use of the mineral solution of Ueda (UM). In addition, no significant differences were observed between the cultivars Vanda and Thaís, regardless of the solution used (Figure 1).

Table 2. Analysis of variance for crown diameter (CD), root length (RL), stem diameter (SD) and leaf area (LA) as a function of the different crisp lettuce cultivars and nutrient solutions

\begin{tabular}{lccccc}
\hline \multirow{2}{*}{$\begin{array}{c}\text { Source } \\
\text { of variation }\end{array}$} & DF & \multicolumn{4}{c}{ Mean square } \\
\cline { 3 - 6 } Treatment & 23 & $100.07^{\star \star}$ & $40.60^{\star \star}$ & $16.61^{\star *}$ & $0.21^{\star \star}$ \\
Solution (S) & 7 & $286.40^{\star \star}$ & $120.43^{\star \star}$ & $43.85^{\star \star}$ & $0.668^{\star \star}$ \\
Block & 2 & $34.00^{\star *}$ & $9.24^{\text {ns }}$ & $7.17^{\text {ns }}$ & $0.006^{\text {ns }}$ \\
Residual (a) & 14 & 4.14 & 23.04 & 3.97 & 0.032 \\
Cultivar (C) & 2 & $99.08^{\star *}$ & $24.16^{\star}$ & $22.12^{\star *}$ & $0.013^{\text {ns }}$ \\
S x C & 14 & $7.04^{*}$ & $3.04^{\text {ns }}$ & $2.20^{\text {ns }}$ & $0.023^{\text {ns }}$ \\
Residual (b) & 32 & 2.99 & 7.29 & 1.74 & 0.016 \\
CVa (\%) & & 6.79 & 28.13 & 14.72 & 5.11 \\
CVb (\%) & & 5.78 & 15.83 & 9.75 & 3.66 \\
Overall mean & & 29.97 & 17.06 & 13.55 & 3.54 \\
\hline
\end{tabular}

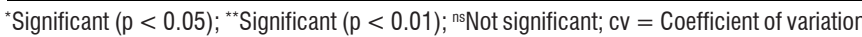
of plot (a) and subplot (b); ${ }^{1}$ Data transformed to $\log (\mathrm{x})$

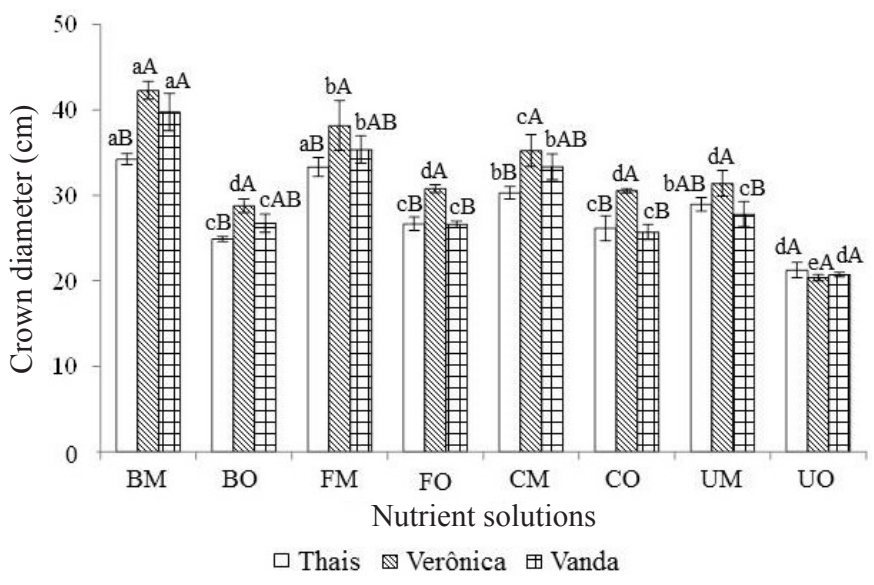

Means followed by the same lowercase letters indicate that the solutions do not differ for the same cultivar and means followed same uppercase letters indicate that the cultivars do not differ for the same solution. Vertical bars represent the mean standard error. Mineral nutrient solutions: Bernardes (BM), Furlani (FM), Castellane \& Araújo (CM) and Ueda (UM); modified nutrient solutions: Bernardes (BO), Furlani (FO), Castellane \& Araújo (CO) and Ueda (UO)

Figure 1. Crown diameter of crisp lettuce cultivars as a function of different nutrient solutions

Working with hydroponic system and solution of Furlani (1995), Feltrim et al. (2005) obtained CD of $23.14 \mathrm{~cm}$, on average, cultivating in the winter the cultivars Lorca, Lucy Brown, Tainá, Great Lakes, Madona and Mesa 659. On the other hand, in the summer season, Feltrim et al. (2009) found mean of $24.34 \mathrm{~cm}$ for the following crisp lettuce cultivars: Marisa, Verônica, Veneza Roxa and Vera. These values, except for the modified solution of Ueda (UO), are lower than those obtained in the present study, regardless of the cultivar. The differences between the results can be related to the climatic differences between the regions in which the experiments were conducted. Still regarding Figure 1, in the follow-up analysis of nutrient solution for each cultivar, the highest CD means of the three studied cultivars were obtained with the mineral solution of Bernardes (BM).

Comparing the solutions of equal chemical composition, i.e., $\mathrm{BM}$ with $\mathrm{BO}, \mathrm{FM}$ with $\mathrm{FO}$ and so on, the highest $\mathrm{CD}$ means were obtained with the use of mineral solutions in all cultivars. This may have occurred because the short cycle of the lettuce crop requires mineral nutrition readily available in the exchange solution, which is not found in an organic substance (biofertilizer) still in process of mineralization (Dias et al., 2009).

Although plants obtained in the modified solutions showed lower mean diameter, there were no losses in size or visual quality, not resulting in reduction of commercial value.

In comparison to the literature, the mean $\mathrm{CD}$ observed in the present study, which was equal to $29.97 \mathrm{~cm}$ (Table 2), is higher than that cited by Luz et al. (2006), who worked with the hydroponic system using the solution of Furlani and found means of $28.02 \mathrm{~cm}$. However, this difference can be associated with the high temperatures recorded in the cultivation environment, because these authors obtained a mean higher than that of the present study. Except for UO, the modified solutions (organomineral) promoted CD results similar to those found by Blat et al. (2011), who evaluated the performance of lettuce cultivars in Ribeirão Preto-SP and found values for crown diameter of 23.2, 24.1 and $22.8 \mathrm{~cm}$ for the cultivars Brasil 221, Maravilha das Quatro Estações and Brasil 303, respectively. 
According to Figure 2A, the solutions BO, FM, FO and UO exhibited the highest values of root length (RL), statistically differing from the other nutrient solutions. The values found for RL with the use of these solutions are superior to $16.5 \mathrm{~cm}$, reported by Monteiro Filho et al. (2014) for lettuce cultivation using organomineral solutions in floating hydroponic system.

Still according to Figure 2A, it is supposed that non-mineral substances, such as humic acid, from modified solutions, contributed to the higher root length in lettuce plants. Investigating the influence of humic acids on the production of lettuce seedlings, Bezerra et al. (2007) observed increase of 26.2\% in RL. Regarding the cultivars (Figure 2B), Verônica and Thaís exhibited the highest RL and the latter did not differ from the cultivar Vanda.

The highest values of stem diameter were obtained with the use of mineral hydroponic solutions, which did not differ statistically (Figure 2C), and there was also no significant difference between the modified solutions. As to the cultivars, the highest stem diameter was obtained by the cultivar Verônica, which differed statistically from the others (Figure 2D).
The values of stem diameter observed in the present study were superior to the mean of $9.4 \mathrm{~mm}$ reported by Gonçalves et al. (2010), in a study conducted with doses of organic fertilization in the lettuce crop with localized irrigation system. Regarding the use of organic products in lettuce nutrition, Santi et al. (2013) evaluated the agronomic performance of lettuce fertilized with filter cake (residue of sugar and alcohol industry), plus a dose of 150-300-90 kg ha-1 of N-P-K in protected environment, and found values of 18,17 and $16 \mathrm{~mm}$ for the cultivars Rafaela, Júlia and Tainá, respectively. These results are superior to those found in the present study with the cultivars Thaís, Vanda and Verônica.

For leaf area, the highest values (data not transformed) occurred in the mineral solutions BM $\left(8885.19 \mathrm{~cm}^{2}\right)$, FM $\left(6650.27 \mathrm{~cm}^{2}\right)$ and $\mathrm{CM}\left(5206.27 \mathrm{~cm}^{2}\right)$, which did not differ significantly. On the other hand, the solution UO led to a smaller leaf area $\left(1025.67 \mathrm{~cm}^{2}\right)$ (Figure $\left.3 \mathrm{~A}\right)$. In addition, among the mineral solutions, UM promoted plants with smaller leaf area $\left(2410.39 \mathrm{~cm}^{2}\right)$. These results corroborate with those of Dias et al. (2009), who observed lower means of leaf area
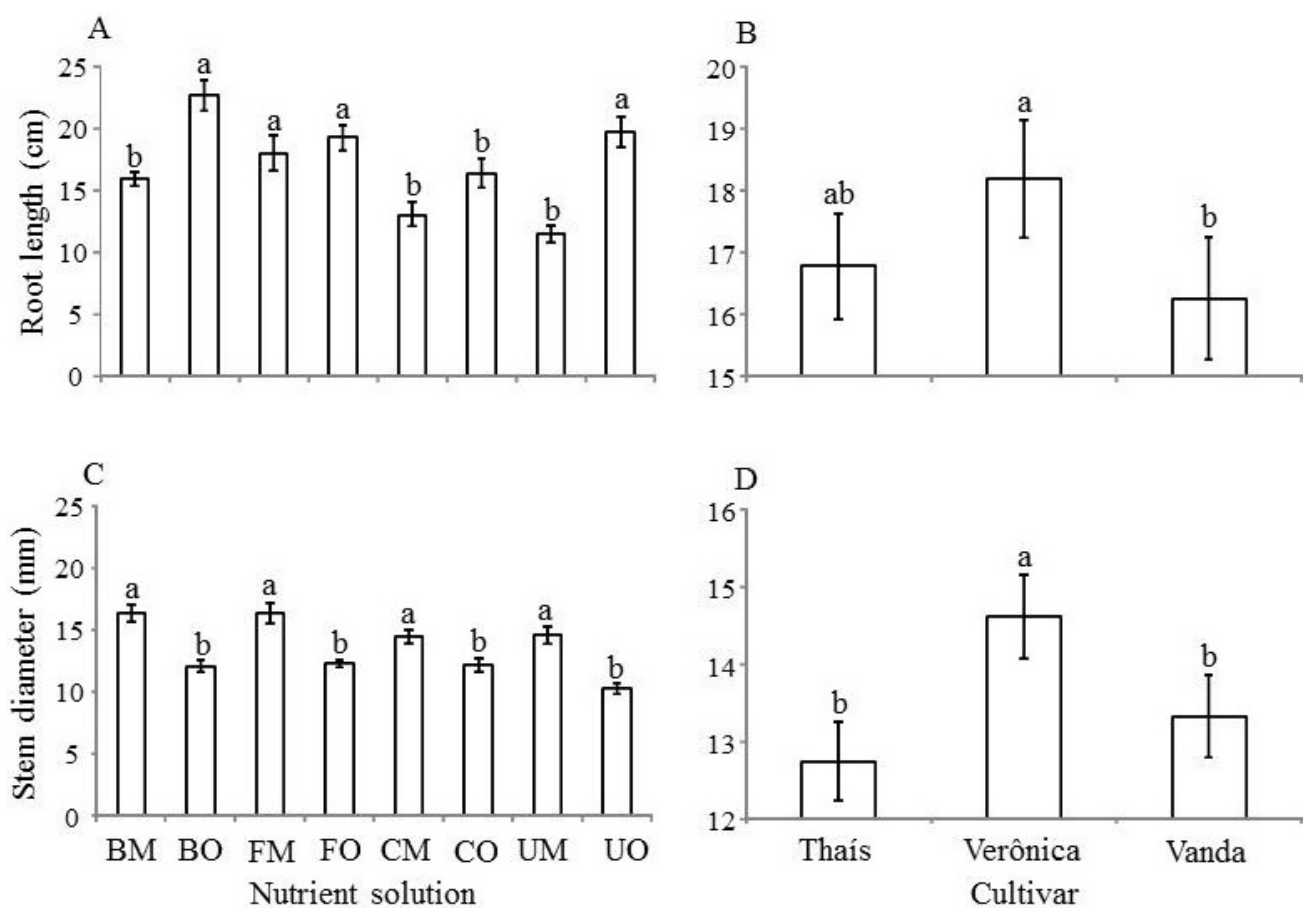

Vertical bars represent the mean standard error. Mineral nutrient solutions: Bernardes (BM), Furlani (FM), Castellane \& Araújo (CM) and Ueda (UM); modified nutrient solutions: Bernardes (BO), Furlani (FO), Castellane \& Araújo (CO) and Ueda (UO)

Figure 2. Root length and stem diameter as a function of the isolated effect of the mineral nutrient solutions (A and C) and cultivars (B and D)
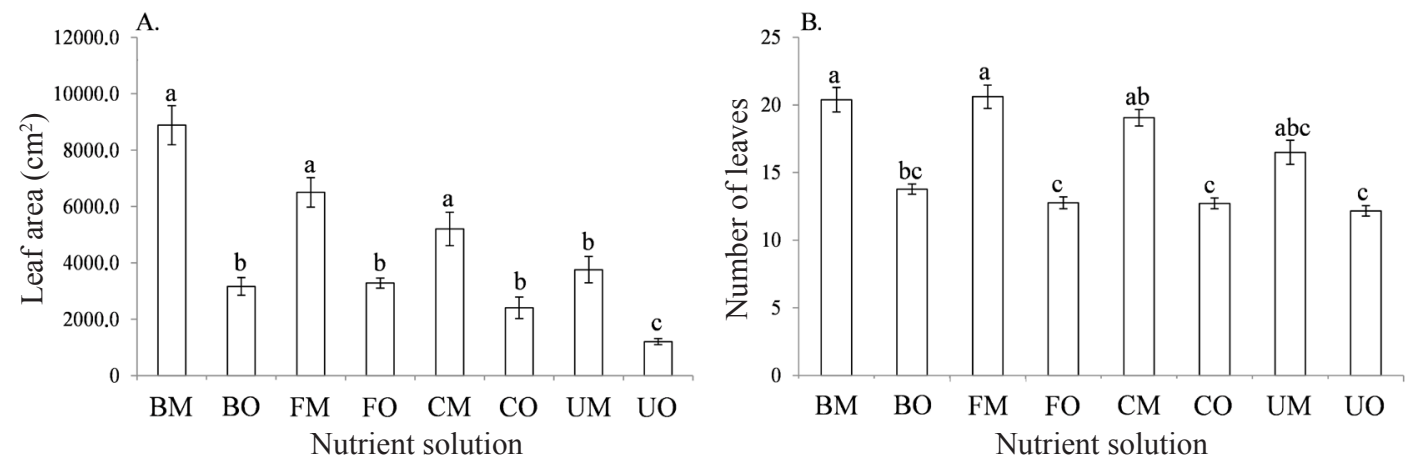

Means followed by the same letter do not differ by Dunn test, at significance level of $(\alpha=0.05), H=53.95$ for number of leaves. Vertical bars represent the mean standard deviation. Mineral nutrient solutions: Bernardes (BM), Furlani (FM), Castellane \& Araújo (CM) and Ueda (UM); modified nutrient solutions: Bernardes (BO), Furlani (F0), Castellane \& Araújo (CO) and Ueda (UO)

Figure 3. Lettuce leaf area (A) and number of leaves (B) as a function of the nutrient solutions 
of hydroponic lettuce with the replacement of the nutrient solution by biofertilizer.

It is important to point out that stem diameter is correlated with leaf area, i.e., with the transpiration rate, because the greater stem diameter is correlated with a greater vascularization of the plant and, consequently, larger leaf area as well (Helbel Júnior et al., 2007). This correlation can be observed in the present study, in which the solutions that promoted greater stem diameter also promoted larger leaf area, corroborating with Dias et al. (2009) and Sá et al. (2013).

Regarding the number of leaves per plant, the highest values were obtained with the use of the mineral solutions $\mathrm{BM}$ and FM, which did not differ from the solutions CM and $\mathrm{UM}$, and the latter also did not differ from any of the modified solutions (Figure 3B). The number of leaves obtained in the present study is lower than the mean of 32 leaves reported by Magalhães et al. (2010), and this difference can be explained by the higher electrical conductivity (EC) of the nutrient solution used by these authors $\left(2.5 \mathrm{dS} \mathrm{m}^{-1}\right)$. Comparing mineral and modified solutions, i.e., BM with BO, FM with FO and so on, the mineral solutions led to higher means of number of leaves, which can be associated with the lower availability of nutrients to the plants with the use of the modified solutions, due to the capacity of adsorption of ions by organic compounds from the biofertilizers used in the production of these solutions, because, regardless of the plot, the EC was maintained close to $1.5 \mathrm{dS} \mathrm{m}^{-1}$.

The use of nutrient solutions containing biofertilizer is reported by Dias et al. (2009) as an important factor, capable of negatively influencing the production performance of hydroponic lettuce. These authors, working with nutrient solution composed of increasing doses of biofertilizer ( 0 , $25,50,75$ and $100 \%)$, concluded that the best results were obtained with $0 \%$ biofertilizer in the nutrient solution. However, different cultivars may exhibit similar responses when fertigated with solutions containing biofertilizer in their composition, as observed by Costa et al. (2006), who evaluated the development of two lettuce cultivars with mineral nutrient solution and nutrient solution based on biofertilizer, and observed that the number of leaves of the cultivar 'Babá de verão' was higher than that of Grand Rapids, when mineral solution was used. However, this behavior was not observed with the use of the solution based on biofertilizer, and their means did not differ.

Except for root length, the lower means of growth variables obtained with the use of modified solutions can be associated with the adsorption of nutrients by organic compounds, reducing the supply of the respective ions to the plants, at a level not equivalent to that of mineral solutions, which corroborates with Monteiro Filho et al. (2014). Additionally, the possible presence of microorganisms in the modified solutions, from the biofertilizer used, can also influence lettuce growth (Jemba \& Alexander, 1999).

\section{Conclusions}

1. The modified solutions promoted superior performance compared with the mineral solutions with the same chemical composition, only for root length.
2. For crown diameter, stem diameter and number of leaves, the mineral solutions promoted the highest means. The smallest leaf area was obtained using the organomineral solution of Ueda.

3. Among the evaluated cultivars, Veronica exhibited the highest means for stem diameter and root length.

\section{Literature Cited}

Alencar, T. A. S.; Tavares, A. T.; Chaves, P. P. N.; Ferreira, T. A.; Nascimento, I. R. Efeito de intervalos de aplicação de urina bovina na produção de alface em cultivo protegido. Revista Verde de Agroecologia e Desenvolvimento Sustentável, v.7, p.53-67, 2012.

APHA - American Public Health Association. Standard methods for the examination of water and wastewater. 20.ed. Washington: American Public Health Association/American Water Works Association/Water Environment Federation, 1998. 1325p.

Ayres, M.; Ayres Júnior, M.; Ayres, D. L.; Santos, A. S. Bioestat 5.0 Aplicações estatísticas nas áreas das ciências biomédicas. Belém: ONG Mamiraua, 2007. 364p.

Benincasa, M. M. P. Análise de crescimento de plantas: Noções básicas. 2.ed. Jaboticabal: FUNEP, 2003. 42p.

Bernardes, L. J. H. Hidroponia da alface: Uma história de sucesso. São Paulo: Estação Experimental de Hidroponia "Alface e Cia", 1997. 135p.

Bezerra, P. S. G.; Grangeiro, L. C.; Negreiros, M. Z.; Medeiros, J. F. Utilização de bioestimulante na produção de mudas de alface. Científica, v.35, p.46-50, 2007.

Blat, S. F.; Sanchez, S. V.; Araujo, J. A. C.; Bolonhezi, D. Desempenho de cultivares de alface em Ribeirão Preto (SP) no cultivo de primavera. Pesquisa \& Tecnologia, v.8, p.1-9, 2011.

Castellane, P. D.; Araújo, J. C. Cultivo sem solo - Hidroponia. SOB Informa, v.13, p.28-29, 1994.

Costa, N. E.; Ribeiro, M. C. C.; Lima, J. S. S.; Cardoso, A. A.; Oliveira, G. L. Utilização de biofertilizante na alface para o sistema hidropônico floating. Revista Verde de Agroecologia e Desenvolvimento Sustentável, v.1, p.41-47, 2006.

Dias, N. da S.; Brito, A. F.; Sousa Neto, O. N. de; Lira, R. B.; Brito, R. F. Produção de alface hidropônica utilizando biofertilizante como solução nutritiva. Revista Caatinga, v.22, p.158-162, 2009.

EMBRAPA - Empresa Brasileira de Pesquisa Agropecuária. Serviço Nacional de Levantamento e Conservação de Solos. Manual de métodos de análise de solo. Rio de Janeiro: Embrapa SNLCS, 1997. 212p.

Feltrim, A. L.; Cecílio Filho, A. B.; Branco, R. B. F.; Barbosa, J. C.; Salatiel, L. T. Produção de alface americana em solo e em hidroponia, no inverno e verão, em Jaboticabal, SP. Revista Brasileira de Engenharia Agrícola e Ambiental, v.9, p.505-509, 2005. https://doi.org/10.1590/S1415-43662005000400010

Feltrim, A. L.; Cecílio Filho, A. B.; Rezende, B. L. A.; Branco, R. B. F. Produção de alface-crespa em solo e em hidroponia, no inverno e verão, em Jaboticabal - SP. Científica, v.37, p.9-15, 2009.

Fernandes, J. D.; Monteiro Filho, A. F.; Chaves, L. H. G.; Gonçalves, C. P.; Cruz, M. P. Formulação de biofertilizante utilizando a ferramenta Solver do Microsoft Office. Revista Verde de Agroecologia e Desenvolvimento Sustentável, v.6, p.101-105, 2011.

Ferreira, D. F. Sisvar: A guide for its bootstrap procedures in multiple comparisons. Ciência e Agrotecnologia, v.38, p.109-112, 2014. http://dx.doi.org/10.1590/S1413-70542014000200001 
Furlani, P. R. Cultivo de alface pela técnica de hidroponia - NFT. Campinas: IAC, 1995. 18p. Documentos, 55

Gonçalves, F. M.; Gomes Filho, R. Carvalho, C. M.; Feitosa, H. O.; Leite, K. N.; Sousa, A. E. C. Níveis de adubação orgânica para o cultivo da alface utilizando sistema de irrigação localizada por gravidade. Revista Brasileira de Agricultura Irrigada, v.4, p.3-13, 2010. https://doi.org/10.7127/rbai.v4n100017

Helbel Júnior, C.; Rezende, R.; Frizzone, J. A.; Santos, H. S.; Dallacort, R. Produção hidropônica da cultura da alface com soluções nutritivas e vazões distintas. Acta Scientiarum Agronomy, v.29, p.391-395, 2007.

Jemba, P. K.; Alexander, M. Possible determinants of rhizosphere competence of bacteria. Soil Biology \& Biochemistry, v.31, p.623632, 1999. https://doi.org/10.1016/S0038-0717(98)00168-0

Lovatto, P. B.; Watthier, M.; Schiedeck G.; Schwengber, J. E. Efeito da urina de vaca como biofertilizante líquido na produção orgânica de mudas de couve (Brassica oleracea var. acephala). Horticultura Brasileira, v.29, p.4571-4577, 2011.

Luz, J. M. Q.; Guimarães, S. T. M. R.; Korndörfer, G. H. Produção hidropônica de alface em solução nutritiva com e sem silício. Horticultura Brasileira, v.24, p.295-300, 2006. https://doi. org/10.1590/S0102-05362006000300005

Magalhães, A. G.; Menezes, D.; Resende, L. V.; Bezerra Neto, E. Desempenho de cultivares de alface em cultivo hidropônico sob dois níveis de condutividade elétrica. Horticultura Brasileira, v.28, p.316-320. 2010. https://doi.org/10.1590/S010205362010000300013
Monteiro Filho, A. F.; Pereira, G. L.; Azevedo, M. R. Q. de A.; Fernandes, J. D.; Azevedo, C. A. V. de. Cultivo hidropônico de cultivares de alface em soluções nutritivas organominerais otimizadas com a ferramenta Solver. Revista Brasileira de Engenharia Agrícola e Ambiental, v.18, p.417-424, 2014. https:// doi.org/10.1590/S1415-43662014000400009

Paulus, D.; Paulus, E.; Nava, G. A.; Moura, C. A. Crescimento, consumo hídrico e composição mineral de alface cultivada em hidroponia com águas salinas. Revista Ceres, v.59, p.110-117, 2012. https://doi.org/10.1590/S0034-737X2012000100016

Potrich, A. C. G.; Pinheiro, R. R.; Schmidt, D. Alface hidropônica como alternativa de produção de alimentos de forma sustentável. Enciclopédia Biosfera, v.8, p.36-48, 2012.

Sá, F. V. da S.; Mesquita, E. F. de; Bertin, A. M. P.; Silva, G. A. da; Costa, J. D. da. Biofertilizantes na produção hidropônica de mudas de mamoeiro. Revista Verde de Agroecologia e Desenvolvimento Sustentável, v.8, p.109-116, 2013.

Santi, A.; Scaramuzza, W. L. M. P.; Neuhaus, A.; Dallacort, R.; Krause, W.; Tieppo, R. C. Desempenho agronômico de alface americana fertilizada com torta de filtro em ambiente protegido. Horticultura Brasileira, v.31, p.338-343. 2013. https://doi.org/10.1590/S0102-05362013000200027 Sarmento, J. D. A.; Morais P. L. D.; Almeida, M. L. B.; Sousa Neto, O. N. de; Dias, N. da S. Qualidade e conservação da alface cultivada com rejeito da dessalinização. Revista Caatinga, v.27, p.90-97, 2014.

Silva, M. L. da; Villela Junior, L. V. E.; Colovatto, G. F.; Sartori, R. A. Produção hidropônica de quatro cultivares de alface em Garça (SP). Revista Científica Eletônica de Agronomia, v.11, p.1-7, 2007. Ueda, S. Hidroponia: Guia prático. São Paulo: Agroestufa, 1990. 50p. 